\title{
ENFERMEIROS APONTAM AS INADEQUADAS CONDIÇÕES DE TRABALHO COMO RESPONSÁVEIS PELA DETERIORAÇÃO DA QUALIDADE DA ASSISTÊNCIA DE ENFERMAGEM
}

\author{
Maria Helena Palucci Marziale*
}

\begin{abstract}
As condições de trabalho dos enfermeiros nos hospitais há muito tempo tem sido consideradas inadequadas devido as especificidades do ambiente e das atividades insalubres executadas.

0 desgaste físico e emocional, a baixa remuneração e o desprestígio social são fatores associados às condições de trabalho do enfermeiro, que vem refletindo negativamente na qualidade da assistência prestada ao cliente, levando ao abandono da profissão e conseqüentemente a escassez de profissionais no mercado de trabalho.

0 USA TODAY em edição de 7 de maio $^{(1)}$ destaca a preocupação de enfermeiros em relação a deterioração dos cuidados de enfermagem em hospitais dos Estados Unidos, Canadá, Alemanha, Inglaterra e Escócia. Uma equipe de pesquisadores liderados por Linda Aiken, da Universidade da Pensilvânia, entrevistou 43.329 enfermeiros de 711 hospitais e constatou que a maioria dos enfermeiros assistenciais declarou-se preocupado em relação à qualidade da assistência prestada aos seus pacientes, sinalizando a falta de pessoal, a insatisfação pelo trabalho e o desgaste emocional pela piora da qualidade do cuidado de enfermagem.

0 desgaste emocional no trabalho em hospitais apresenta altos níveis, segundo a referida pesquisa. Em quatro dos cinco paises avaliados, inclusive nos Estados Unidos, $40 \%$ dos enfermeiros referiram estar insatisfeitos com seu trabalho atual e um em cada cinco enfermeiros, em todas as faixas etárias, afirmou que pretendia deixar o trabalho no período de um ano.

A escassez de enfermeiros no mercado de trabalho americano teve início nas décadas de 80 e 90 , quando muitas jovens decidiram recusar a baixa remuneração e as difíceis condições de trabalho da enfermagem e optar por outras profissões da área da saúde. Conseqüentemente aquelas que ingressam na profissão não estão conseguindo substituir as enfermeiras mais velhas que se aposentam, fato que vem trazendo mudanças na caracterização da força de trabalho, principalmente na idade média do enfermeiro, a qual atualmente é de 42 anos e diante de tal situação, a previsão é que em 2010 seja de 45 anos $^{(1)}$.

A literatura científica tem demonstrado que as condições de trabalho do enfermeiro em vários paises da América do Sul são consideradas piores àquelas vividas pelos enfermeiros americanos e europeus devido a sérias dificuldades políticas e econômicas enfrentadas pelos paises em desenvolvimento.

Sendo o cuidado de enfermagem o objeto de nosso trabalho não podemos aceitar tal situação; para tanto devemos nos mobilizar para melhorar nossas condições de trabalho e continuar executando uma assistência de enfermagem de qualidade cumprindo assim nosso real papel profissional.
\end{abstract}

\section{REFERÊNCIA BILIOGRÁFICA}

1. Fackelinann K. Nursing burnout may lead to major health care crisis. USA TODAY. Monday, 2001 may 7. p. 9.

\footnotetext{
* Presidenta da Comissão de Editoração da Revista Latino-Americana de Enfermagem e Professor Livre-Docente da Escola de Enfermagem de Ribeirão Preto da Universidade de São Paulo, Centro Colaborador da OMS para o desenvolvimento da pesquisa em Enfermagem. E-mail: marziale@eerp.usp.br
} 


\section{NURSES POINT OUT INADEQUATE WORK CONDITIONS RESULTING IN THE DETERIORATION OF NURSING CARE QUALITY}

Maria Helena Palucci Marziale*

Work conditions of hospital nurses have long been considered inadequate due to the specificities of hospital environments and to the insalubrious activities performed.

Physical and emotional burnout, low wages and social depreciation associated with nurses' work conditions have negatively reflected on the quality of the nursing care given to clients, which has resulted in the abandonment of the profession and consequently in the shortage of professionals in the labor market.

The May $7^{\text {th }}$ edition of the USA TODAY ${ }^{(1)}$ points out nurses' concerns regarding the deterioration of nursing care in the United States, Canada, Germany, England and Scotland. A team of researchers led by Linda Aiken, from the University of Pennsylvania, interviewed 43,329 nurses from 711 hospitals and found that most clinical nurses reported to be concerned about the quality of the nursing care given to their patients, which has indicated staff shortage, dissatisfaction at work and emotional burnout due to the worsening of standards in nursing care quality.

According to the interview, the levels of emotional burnout at hospital work is high. In four of the five studied countries, including the United States, $40 \%$ of the nurses reported to be dissatisfied about their present jobs and one out of every five nurses, in all age ranges, reported the intention to quit their jobs within a year.

The shortage of nurses in the American labor market started in the 1980s and 1990s, when many young people decide to decline the low wages and difficult work conditions in Nursing and choose other professions in the health field. Consequently, those who enter the profession have not been able to replace older nurses who retire. This fact has brought about changes in the characterization of the work force, particularly the aspect concerning the nurse's average age, which is presently 42 years and, in face of this situation, is forecast to be 45 years in $2010^{(1)}$.

Scientific literature has shown that nurses' work conditions in various Latin American countries are considerably worse than those experienced by North-American and European nurses due to the serious political and economic difficulties faced by developing countries.

Since nursing care is the objective of our work, we cannot accept this situation, and, therefore, we must organize ourselves in order to improve our work conditions and continue giving good quality nursing care, thus playing our real professional role.

\section{REFERENCE}

1. Fackelinann K. Nursing burnout may lead to major health care crisis. USA TODAY. Monday, 2001 may 7. p. 9.

* President of the Publishing Committee of Revista Latino-Americana de Enfermagem and Associate Professor at the University of São Paulo at Ribeirão Preto College of Nursing, WHO Collaborating Center for Nursing Research Development. E-mail: marziale@eerp.usp.br 


\title{
ENFERMEROS DESCRIBEN LAS INADECUADAS CONDICIONES DE TRABAJO RESPONSABLES POR LA DETERIORACIÓN DE LA CALIDAD DE LA ATENCIÓN DE ENFERMERÍA
}

\author{
Maria Helena Palucci Marziale*
}

Las condiciones de trabajo de los enfermeros en los hospitales, hace mucho tiempo han sido consideradas inadecuadas debido a las especificidades del ambiente y de las actividades insanas ejecutadas.

El desgaste físico y emocional, la baja remuneración y el desprestigio social son factores asociados a las condiciones de trabajo del enfermero, que vienen influyendo negativamente en la calidad de la atención brindada al cliente, llevando al abandono de la profesión de por consiguiente a la escasez de profesionales en el mercado de trabajo.

EI USA TODAY en la edición del 7 de mayo ${ }^{(1)}$ destaca la preocupación de los enfermeros en relación con el deterioro de los cuidados de enfermería en hospitales de Estados Unidos, Canadá, Alemania, Inglaterra y Escocia. Un equipo de investigadores liderados por Linda Aiken, de la Universidad de Pennsylvania, entrevistó 43.329 enfermeros de 711 hospitales y constató que la mayoría de los enfermeros asistenciales se declaro preocupado en relación con la calidad de la atención prestada a sus pacientes, señalizando la falta de personal, la insatisfacción por el trabajo y el desgaste emocional, como los factores que empeoran la calidad del cuidado de enfermería.

El desgaste emocional en el trabajo hospitalario presenta altos niveles, según la investigación referida. En 4 de los 5 países evaluados, inclusive en los Estados Unidos, $40 \%$ de los enfermeros refirieron estar insatisfechos con su actual trabajo y 1 de cada 5 enfermeros, en todas las fajas etáreas, afirmó que pretendía dejar su trabajo en el periodo de un año.

La escasez de enfermeros en el mercado de trabajo americano tuvo inicio en las décadas de los 80's y 90's, cuando muchas jóvenes decidieron rechazar la baja remuneración y las difíciles condiciones de trabajo de enfermería y optar por otras profesiones del área de salud. Consecuentemente, aquellas que ingresan en la profesión no están consiguiendo sustituir las enfermeras más viejas que se jubilan, hecho que viene produciendo cambios en la caracterización de la fuerza de trabajo, principalmente en el promedio de edad del enfermero que actualmente es de 42 años y frente a ésta situación, la previsión es que en el 2010 sea de 45 años ${ }^{(1)}$.

La literatura científica ha demostrado que las condiciones de trabajo del enfermero en varios países de América del Sur son consideradas peores que las que viven los enfermeros americanos y europeos debido a las serias dificultades políticas y económicas que enfrentan los países en desarrollo.

Siendo el cuidado de enfermería el objeto de nuestro trabajo, no podemos aceptar tal situación. Por lo tanto, debemos movilizarnos para mejorar nuestras condiciones de trabajo y continuar ejecutando una atención de enfermería de calidad, cumpliendo así nuestro real papel profesional.

\section{REFERENCIA BIBLIOGRÁFICA}

1. Fackelinann K. Nursing burnout may lead to major health care crisis. USA TODAY. Monday, 2001 may 7. p. 9.

* Presidenta de la Comisión Editorial de la Revista Latinoamericana de Enfermería y Profesor Libre-Docente de la Escuela de Enfermería de Ribeirão Preto de la Universidad de São Paulo, Centro Colaborador de la OMS para el desarrollo de la Investigación en Enfermería. E-mail: marziale@eerp.usp.br 
